\title{
Factors associated with serum lipids of adolescents from the Brazilian South ${ }^{1}$
}

\author{
Fatores associados aos lípides séricos \\ em adolescentes no Sul do Brasil
}

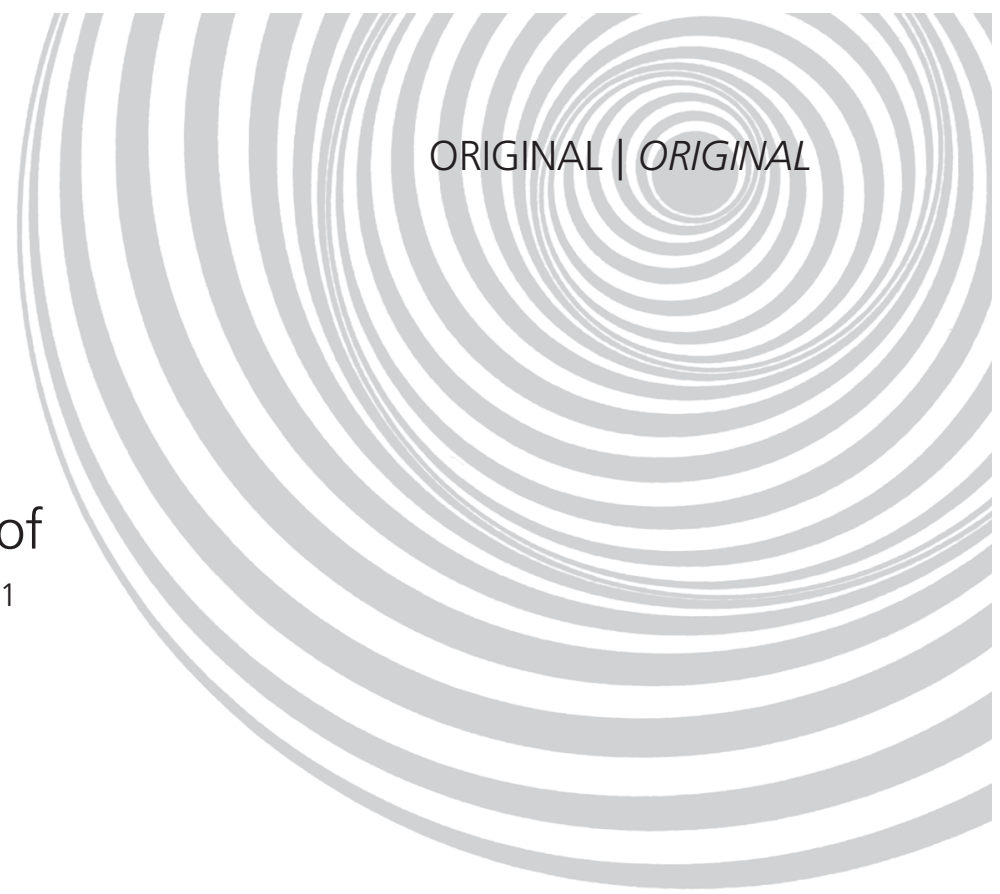

Carmem Cristina BECK²

Adair da Silva LOPES $^{3}$

José Cazuza de FARIAS JÚNIOR ${ }^{4}$

A B S T R A C T

\section{Objective}

This study analyzes factors associated with serum lipids in adolescents from southern Brazil.

\section{Methods}

This is a school-based cross-sectional study with a probabilistic sample composed of 660 adolescents aged 14 to 19 years from the city of Três de Maio, Rio Grande do Sul state, Brazil. The following independent variables were analyzed: body mass index; waist-to-height ratio; moderate to vigorous level of physical activity; sedentary behaviour; lipid, total saturated fatty acid, cholesterol, sodium, and fiber intakes; smoking; and alcohol abuse. Linear regression analysis tested the association between the independent variables and total cholesterol and high density lipoprotein-cholesterol.

\section{Results}

Body mass index was directly associated with total cholesterol $(\beta=0.96, p=0.001)$ and reversely associated with high density lipoprotein-cholesterol $(\beta=-0.45, p<0.001)$.

\section{Conclusion}

High body mass index may have a negative impact on the lipid profile of adolescents. Thus, monitoring nutritional status is important to prevent and control dyslipidemia in adolescents. We suggest multidisciplinary and intersectoral actions that encourage teenagers to acquire a healthy lifestyle, with emphasis on the adoption of an active lifestyle and balanced diet.

Indexing terms: Adolescent. Cholesterol. Diet. Obesity. Physical activity. Risk factors.

1 Article based on the doctoral thesis of the CC BECK intitled "Pressão arterial e lipides séricos em adolescentes: estudo com ênfase em variáveis antropométricas e do estilo de vida". Universidade Federal de Santa Catarina; 2011.

2 Instituto Federal de Santa Catarina. R. João Bernardino da Rosa, Campus Palhoça Bilíngue, s/n., Cidade Universitária Pedra Branca, 88137-010, Palhoça, SC, Brasil. Correspondência para/Correspondence to: CC BECK. E-mail: <carmembeck@hotmail.com>.

3 Universidade Federal de Santa Catarina, Centro de Desportos, Departamento de Educação Física. Florianópolis, SC, Brasil.

${ }^{4}$ Universidade Federal da Paraíba, Centro de Ciências da Saúde, Departamento de Educação Física. João Pessoa, PB, Brasil. 


\section{RE S U M O}

\section{Objetivo}

Analisar fatores associados aos lípides séricos em adolescentes no Sul do Brasil.

\section{Métodos}

Estudo transversal de base escolar com amostra probabilística composta por 660 adolescentes de 14 a 19 anos de idade do município de Três de Maio, Rio Grande do Sul, Brasil. As variáveis independentes analisadas foram: indice de massa corporal, razão cintura-estatura, atividade física moderada a vigorosa, comportamentos sedentários, ingestão de lipídeos, de ácidos graxos saturados totais, de sódio e de fibras, colesterol, tabagismo e consumo abusivo de álcool. A associação entre as variáveis independentes e o colesterol total e as lipoproteínas de alta densidade foi testada por meio da análise de regressão linear.

\section{Resultados}

$O$ indice de massa corporal se mostrou associado de forma direta ao colesterol total $(\beta=0,96 ; p=0,001)$ e inversa à lipoproteína de alta densidade $(\beta=-0,45 ; p<0,001)$.

\section{Conclusão}

A elevação do índice de massa corporal pode contribuir para alterações negativas no perfil lipídico de adolescentes; o monitoramento do estado nutricional representa, assim, uma estratégia importante para prevenção e controle das dislipidemias em adolescentes. Sugerem-se ações de caráter multidisciplinar e intersetorial que estimulem nos adolescentes hábitos saudáveis, com ênfase na aquisição de um estilo de vida ativo e de uma alimentação equilibrada.

Termos de indexação: Adolescente. Colesterol. Dieta. Obesidade. Atividade física. Fatores de risco.

\section{INTRODUCTION}

Despite the global strategies and actions to control and reduce cardiovascular diseases, they continue to have high morbidity and mortality'. Cardiovascular events are mainly caused by atherosclerosis, which is associated with risk factors found in young individuals ${ }^{2,3}$.

Among the risk factors, serum lipids in excess of the recommended levels are directly associated with the atherosclerotic process. Atherosclerosis is generated by cholesterol and cholesterol ester deposits in the intima of the great arteries. During adolescence, depending on lifestyle and genetic factors, some fatty streaks accumulate more lipids, forming a lesion called fibrous plaque that grows, calcifies, bleeds, ulcers, ruptures, or thromboses over the years, resulting in clinical manifestations or cardiovascular events ${ }^{4}$. Hence, one of the goals to promote cardiovascular health and reduce diseases is to control cholesterol levels in all age groups ${ }^{1}$.

There is a growing prevalence of dyslipidemia in the youth. Moreover, serum levels of lipids and lipoproteins in children and adolescents tend to remain unchanged during adulthood, justifying the concern with these age groups $^{5,6}$. In Brazilian adolescents, the prevalences of undesirable lipid levels vary from $20.3 \%^{7}$ to $51.0 \%^{8}$ for total cholesterol and from $5.0 \%{ }^{9}$ to 25.9\% ${ }^{7}$ for High Density Lipoprotein-cholesterol $(\mathrm{HDL}-\mathrm{c})$. Similar variations have been found in other countries ${ }^{10,11}$. Many factors have been associated with dyslipidemia in adolescents, such as socio-environmental conditions, behavior patterns, genes, low birth weight, and excess

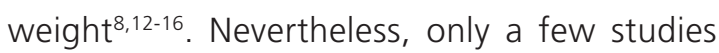
explore the relationship between serum lipids and anthropometric and lifestyle variables, considered important confounding factors.

Knowing the relationship between multiple risk factors and serum lipids in adolescents, especially modifiable risk factors, is critical for public health, since early interventions are possible. The objective of this study was to analyze the factors associated with serum lipids in adolescents from the Brazilian South. 


\section{METHODS}

This study is linked to an epidemiologic, school-based survey done in 2006 with adolescents from Três de Maio (RS), Brazil, called "Risk factors for atherosclerosis in adolescents". The study was approved by the Human Research Ethics Committee from the Universidade Federal de Santa Catarina (UFSC) under Protocol number 41/2006, and all participants or their guardians signed an Informed Consent Form.

Três de Maio is a town in the Northwestern region of the state of Rio Grande do Sul, a state in the Brazilian South region. The resident population in 2006 was 24,245 inhabitants, and 2,209 were aged 10 to 14 years and 2,236 were aged 15 to 19 years ${ }^{17}$. Most of the population descend from Germans, Italians, and Poles.

\section{Sample}

The study population $(n=1,642)$ consisted of adolescents aged 14 to 19 years enrolled in the public and private schools of the town in 2006. The sample size was based on the prevalence of one of the main survey outcomes that motivated this study: a prevalence of physical inactivity of $40.0 \%$, a confidence interval of $95.0 \%$, a sampling error of $3.5 \%$, resulting in a sample size of 516 adolescents; $40.0 \%$ more students were added to compensate for losses and refusals. This resulted in a final sample of 723 adolescents.

Sampling was probabilistic, stratified, and proportional to the socioeconomic status and sex distributions in the town. At first the schools were characterized by socioeconomic status proxy (public and private schools). All schools offering elementary and secondary education, as well as technical courses, were included in the study (5 public and 2 private schools).

In the sequence, all students of each school aged 14 to 19 years were listed and ordered alphabetically by gender. The study participants were selected systematically and the interval defined by dividing the total number of adolescents in each list by the number of students who should be included in each school.

\section{Data collection}

Data were collected in June and July of 2006 by a trained team of different professionals who participated in a pilot study. The following sociodemographic data were collected: gender, age, skin color (self-reported), and economic class according to the Associação Brasileira de Empresas de Pesquisa (ABEP, Brazilian Association of Market Research) criteria $^{18}$. The adolescents were also asked about their family history of high cholesterol and early myocardial infarction as follows: "Does anyone in your family have high cholesterol level?" (No; I don't know; mother; father; siblings); "Has anyone in your family had an acute myocardial infarction before age 55 years?" (No; I don't know; mother; father; siblings). The answer "I don't know" was entered as missing. The adolescent's birth weight was informed by one of the parents.

The level of physical activity was measured by a validated questionnaire ${ }^{19}$ that has been used in studies with Brazilian adolescents. The adolescents informed the number of days per week (frequency) and duration (minutes per day) of the moderate and vigorous physical activity practiced in the last seven days. A list containing 18 physical activities was used with a space reserved for adding other activities. The level of physical activity was determined by multiplying the frequency by the duration, resulting in a score of minutes per week.

Sedentary behaviour (hours/day) was given by the weighted average of the total screen time spent by adolescents on weekdays (Monday through Friday) and weekend days (Saturday and Sunday) in front of a television/videogame/ computer.

Diet was assessed by a dietary recall that included the foods and beverages consumed on a typical or normal day within the past 15 days. 
Photographs, food replicas, and a set of cooking units were used for minimizing the error sources such as memory bias and cooking unit size. The adolescents were asked about the type and amount, in cooking units, of each food consumed in each of the meals (breakfast, snacks, lunch, and supper). Total energy and nutrient intakes (lipids (g), total saturated fatty acids (g), cholesterol (mg), sodium (mg), and fibers (g)) were calculated by the software DietPro 4.020.

Smoking and alcohol abuse were assessed by the Global School-Based Student Health Survey ${ }^{21}$. Anyone who smoked on one or more days in the past 30 days was considered a smoker, regardless of amount. Alcohol abuse was defined as the consumption of five or more doses on one occasion in the last 30 days.

The anthropometric measurements were taken twice by the same researcher (technical measuring error $<1 \%$ ) and the final result was given by the average of the two. Body Mass Index (BMI) was given by dividing the weight in kilograms by the square of the height in meters; weight and height were measured as described elsewhere ${ }^{22}$. An electronic scale of the brand Filizola ${ }^{\circledR}$ with stadiometer was used for the measurements. Waist circumference was measured by a fiberglass tape measure (Mabis) at the midpoint between the last rib and the iliac crest - also measured twice and the average used. The Waist-to-Height Ratio (WHR) was given by dividing the waist circumference in centimeters by the height in centimeters.

Blood was collected from a vein on the inside of the elbow after a 10- to 12-hour fast with the individual in the seated position to determine total cholesterol $(\mathrm{mg} / \mathrm{dL}$ ) and $\mathrm{HDL}-\mathrm{C}$ $(\mathrm{mg} / \mathrm{dL})$. Collection was done at the school by a biochemist. The determinations were done by the automated device BioSystems, model BTS 370 Plus.

\section{Statistical analysis}

Descriptive measures (means and standard deviations) were calculated for the quantitative variables and frequency distribution for the categorical variables. The Student's $t$ test for independent samples was used for comparing the mean values of the quantitative variables and the Chi-square test for comparing the proportions of the qualitative variables of male and female adolescents.

Simple and multiple regression analyses were used for analyzing the association between the dependent variables (total cholesterol and $\mathrm{HDL}-\mathrm{C}$ ) and the following independent variables: BMI; WHR; moderate and vigorous physical activity (minutes per week); inactivity (hours per day); smoking (yes=1; no=0); and lipid (g), total saturated fatty acid (g), cholesterol (mg), sodium (mg), and fiber ( $\mathrm{g}$ ) intakes. Nutrient intake was adjusted to total calorie intake, which is given by the residues of linear regression models where nutrient intake and total calories are the dependent and independent variables, respectively. This technique is recommended for epidemiologic nutritional assessments. The procedure allows assessing the influence of consuming a certain nutrient on the occurrence of a disease, cancelling the influence caused by the total energy intake on the outcome of what is being investigated ${ }^{23}$. After the variable physical activity (minutes per week) was transformed into $\log 10$, it presented a positive asymmetric distribution. One was added to the physical activity scores to allow the logarithmic transformation given that some students admitted to being inactive (score of zero).

In adjusted multivariate analysis, all independent variables were included in the model, regardless of the $p$ value obtained in the unadjusted model. The variables were selected by backward selection. The variables that remained in the model were those with $p<0.10$. The same criterion was used for potential confounding factors, namely gender (female $=0$; male $=1)$, decimal age in years, skin color ( white $=0$; non-white $=1$ ), economic class (classes $A / B=0, C=1, D / E=2)$, family history of high cholesterol (yes $=1 ; \mathrm{no}=0$ ), family history of early myocardial infarction (yes $=1 ; n o=0$ ), and low birth 
weight $(<2500 \mathrm{~g})$. Variables with $p \leq 0.05$ were considered to be associated with total and HDL-c.

Multicollinearity was checked by determining the Variance Inflation Factors (VIF) and correlation coefficients between the independent variables. VIF varied from 1.03 to 2.08, and the correlation coefficients remained below 0.56, indicating the absence of multicollinearity. Waist circumference was not used in the analysis because it is highly correlated with BMI ( $r=0.89$ ). The adequacy of the final models was tested by analyzing residues, adjusting the determination coefficient, adding the regression residue squares, testing regression residue normality, and analyzing.

\section{RE S U L T S}

The sample consisted of 660 adolescents, 317 males and 343 females, after a sample loss of $8.8 \%$. For this study the a posteriori statistical power of the sample showed that this number of participants allows estimating determination coefficients of any magnitude with up to 13 predictors (independent variables). It also used a confidence level of $95 \%, \alpha=5.0 \%$, and $1-\beta=80.0 \%$.
The sociodemographic characteristics of the adolescents and the descriptive values of the study variables are shown in Tables 1 and 2, respectively. The prevalences of some variables were as follows: low birth weight, $8.9 \%(n=59)$; family history of high cholesterol, $49.7 \%(n=328)$; and family history of early acute myocardial infarction, $14.5 \%(n=96)$. The mean age, body

Table 1. Sociodemographic characteristics of the study adolescents from Três de Maio (RS), Brazil 2006.

\begin{tabular}{lccc}
\hline Variables & $\mathrm{n}$ & $\%$ & $(95 \% \mathrm{Cl})$ \\
\hline Gender & & & \\
Male & 317 & 48.0 & $(42.3-54.6)$ \\
Female & 343 & 52.0 & $(46.5-57.3)$ \\
Age & & & \\
14-15 years & 238 & 36.1 & $(30.0-42.6)$ \\
16-17 years & 337 & 51.0 & $(45.6-56.5)$ \\
18-19 years & 85 & 12.9 & $(6.6-22.0)$ \\
Skin color & & & \\
White & 487 & 73.8 & $(69.6-77.6)$ \\
Non-white & 173 & 26.2 & $(19.6-33.2)$ \\
Economic class & & & \\
A, B & 240 & 36.4 & $(30.2-42.7)$ \\
C & 312 & 47.3 & $(41.8-53.1)$ \\
D, E & 108 & 16.3 & $(10.2-25.1)$ \\
\hline
\end{tabular}

Note: Economic class: A,B: high; C: average; D,E: low. $95 \% \mathrm{Cl}$ : Confidence Interval of $95 \%$.

Table 2. Study variable means \pm standard deviations and percentages. Três de Maio (RS), Brazil, 2006.

\begin{tabular}{|c|c|c|c|c|c|c|c|}
\hline \multirow{2}{*}{ Variables } & \multicolumn{2}{|c|}{ All $(n=660)$} & \multicolumn{2}{|c|}{ Male $(n=317)$} & \multicolumn{2}{|c|}{ Female $(n=343)$} & \multirow{2}{*}{$p$-value } \\
\hline & M & SD & M & SD & M & SD & \\
\hline Total cholesterol (mg/dL) & 151.1 & 27.1 & 145.0 & 25.8 & 156.6 & 27.1 & $<0.001$ \\
\hline $\mathrm{HDL}-\mathrm{c}(\mathrm{mg} / \mathrm{dL})$ & 53.0 & 11.8 & 49.4 & 10.8 & 56.4 & 11.7 & $<0.001$ \\
\hline Body mass index $\left(\mathrm{kg} / \mathrm{m}^{2}\right)$ & 21.3 & 3.5 & 21.3 & 3.1 & 21.3 & 3.8 & 0.828 \\
\hline Waist-to-height ratio & 0.44 & 0.05 & 0.43 & 0.04 & 0.44 & 0.05 & 0.005 \\
\hline Physical activity* (min/week) & 319.3 & 310.8 & 401.8 & 378.0 & 243.1 & 204.9 & $<0.001$ \\
\hline Sedentary behaviour (h/day) & 4.4 & 2.4 & 4.2 & 2.5 & 4.5 & 2.2 & 0.230 \\
\hline Lipids (g) & 103.9 & 60.1 & 118.1 & 67.0 & 90.7 & 49.6 & $<0.001$ \\
\hline Total SFA (g) & 23.5 & 16.8 & 29.5 & 18.2 & 17.9 & 13.1 & $<0.001$ \\
\hline Cholesterol (mg) & 237.9 & 167.3 & 300.1 & 187.5 & 180.4 & 120.6 & $<0.001$ \\
\hline Sodium (mg) & $2,967.9$ & $1,640.4$ & $3,696.3$ & $1,733.9$ & $2,294.7$ & $1,208.7$ & $<0.001$ \\
\hline Fibers $(g)$ & 26.9 & 19.6 & 33.08 & 21.2 & 21.2 & 16.1 & $<0.001$ \\
\hline Smoking ( $\geq 1$ day/30days, \%, n) & 6.8 & 45.0 & 8.5 & 27.0 & 5.3 & 18.0 & 0.096 \\
\hline Alcohol ( $\geq 5$ doses/occasion, $\%, n)$ & 40.0 & 264.0 & 50.8 & 161.0 & 30.0 & 103.0 & $<0.001$ \\
\hline
\end{tabular}

Note: *Moderate and vigorous physical activity. The Student's $t$ test compared continuous variables of independent samples and the Chi-square test compared percentages.

HDL-c: High Density Lipoprotein-cholesterol; SFA: Saturated Fatty Acids; M: Mean; SD: Standard Deviation. 
weight, and body height, and respective standard deviations were respectively $16.05 \pm 1.34$ years, $63.96 \pm 11.65$ kilos, and $1.73 \pm 0.07$ meters for boys and $15.76 \pm 1.33$ years, $56.37 \pm 10.86$ kilos, and $1.62 \pm 0.06$ meters for the girls (data not in the Tables).

The girls had higher total and HDL-c means than the boys $(p<0.001)$. The boys consumed more lipids, total saturated fatty acids, cholesterol, sodium, and fibers, and abused alcohol more frequently. Girls also had higher waist-to-height ratio and spent fewer minutes doing moderate and vigorous physical activities (Table 2).

Tables 3 and 4 show the results of regression analysis for the factors associated with serum lipids in the study sample. Total cholesterol was positively associated with BMI and negatively associated with HDL-C.

The final multiple regression model for total cholesterol (Table 3) showed a direct association between BMI adjusted for gender and family history of early myocardial infarction, while the final HDL-c model (Table 4) presented an inverse association with BMI adjusted for gender.
DISCUSSION

There is a significant linear relationship between BMI and serum total and HDL-C, suggesting that adolescents with high BMI tend to have high total cholesterol and low HDL-C.

Lifestyle-related variables, namely physical activity; sedentary behaviour; fiber, fat, and cholesterol intakes; smoking; and alcohol abuse were not associated with serum lipids in adolescents. Guedes et al. ${ }^{12}$ have also not found an association between physical activity and total and HDL-c. However, LeBlanc \& Janssen ${ }^{24}$ found that small amounts of moderate to vigorous physical activity reduced the risk of low HDL-c levels. Moreover, studies suggest that a diet high in fats, cholesterol, and sodium, and poor in fibers can have a negative impact on the lipid profile of adolescents $^{12,16}$.

The lack of an association between lifestyle variables and total and HDL-C has various explanations. Regarding physical activity, the use of a questionnaire to determine its level may underestimate or overestimate the level and lead to the lack of association with certain outcomes.

Table 3. Simple and multiple linear regression analysis of total cholesterol and anthropometric and lifestyle variables of adolescents from Três de Maio (RS), Brazil, 2006.

\begin{tabular}{|c|c|c|c|c|c|c|}
\hline \multirow{3}{*}{ Variables } & \multicolumn{6}{|c|}{ Total cholesterol (mg/dL) } \\
\hline & \multicolumn{3}{|c|}{ Unadjusted analysis } & \multicolumn{3}{|c|}{ Adjusted analysis } \\
\hline & $\beta$ & SEM & $p$ value & $\beta^{\dagger}$ & SEM & $p$-value \\
\hline Body mass index $\left(\mathrm{kg} / \mathrm{m}^{2}\right)$ & 0.995 & 0.301 & 0.001 & -0.957 & 0.294 & 0.001 \\
\hline Waist-to-height ratio & -54.74 & 22.94 & 0.017 & -35.97 & 22.92 & 0.117 \\
\hline Physical activity ${ }^{*}$ & -1.655 & 2.160 & 0.444 & 0.671 & 2.221 & 0.763 \\
\hline Sedentary behaviour (h/day) & -0.409 & 0.441 & 0.354 & -0.665 & 0.456 & 0.145 \\
\hline Lipids & -0.014 & 0.030 & 0.636 & -0.035 & 0.039 & 0.372 \\
\hline Total SFA & -0.170 & 0.078 & 0.030 & -0.027 & 0.110 & 0.805 \\
\hline Cholesterol & -0.015 & 0.008 & 0.043 & -0.005 & 0.009 & 0.560 \\
\hline Sodium & -0.002 & 0.001 & 0.011 & 0.000 & 0.001 & 0.998 \\
\hline Fibers & -0.130 & 0.065 & 0.045 & -0.120 & 0.084 & 0.154 \\
\hline Smoking ( $\geq 1$ day/30days) & 1.414 & 4.188 & 0.785 & 1.692 & 4.271 & 0.692 \\
\hline Alcohol ( $\geq 5$ doses/occasion) & -2.679 & 2.152 & 0.214 & -1.805 & 2.278 & 0.428 \\
\hline
\end{tabular}

Note: "Moderate and vigorous physical activity - converted to log 10; SFA: Saturated Fatty Acids; SEM: Standard Error of Measurement; Lipids, SFA, sodium, and fibers adjusted for total calories. ${ }^{\dagger}$ Final model adjusted for gender $(p<0.001)$ and family history of acute myocardial infarction ( $\left.p=0.061\right)$. Low birth weight $(p=0.69)$; skin color $(p=0.640)$; family history of high cholesterol $(p=0.254)$; economic class $(p=0.135)$, age $(p=0.129)$ were excluded from the model because $p \geq 0.10$. 
Table 4. Simple and multiple linear regression analysis for high-density lipoprotein cholesterol (HDL-C) and anthropometric and lifestyle variables of adolescents from Três de Maio (RS), Brazil, 2006.

\begin{tabular}{|c|c|c|c|c|c|c|}
\hline \multirow{3}{*}{ Variables } & \multicolumn{6}{|c|}{$\mathrm{HDL}-\mathrm{c}(\mathrm{mg} / \mathrm{dL})$} \\
\hline & \multicolumn{3}{|c|}{ Unadjusted analysis } & \multicolumn{3}{|c|}{ Adjusted analysis } \\
\hline & $\beta$ & SEM & $p$-value & $\beta^{\ddagger}$ & SEM & $p$-value \\
\hline Body mass index $\left(\mathrm{kg} / \mathrm{m}^{2}\right)$ & -0.445 & 0.131 & 0.001 & -0.453 & 0.125 & $<0.001$ \\
\hline Waist-to-height ratio & -5.939 & 10.025 & 0.554 & 0.088 & 9.817 & 0.993 \\
\hline Physical activity* & -1.695 & 0.938 & 0.071 & -0.046 & 0.951 & 0.962 \\
\hline Sedentary behaviour (h/day) & -0.182 & 0.192 & 0.344 & -0.277 & 0.195 & 0.157 \\
\hline Lipids & 0.003 & 0.013 & 0.811 & -0.005 & 0.017 & 0.755 \\
\hline Total SFA & -0.034 & 0.034 & 0.315 & 0.020 & 0.047 & 0.669 \\
\hline Cholesterol & -0.005 & 0.003 & 0.142 & -0.001 & 0.004 & 0.762 \\
\hline Sodium & 0.000 & 0.000 & 0.309 & 0.000 & 0.001 & 0.401 \\
\hline Fibers & -0.021 & 0.028 & 0.464 & -0.008 & 0.036 & 0.822 \\
\hline Smoking ( $\geq 1$ day/30days) & 0.456 & 1.823 & 0.802 & 1.287 & 1.829 & 0.482 \\
\hline Alcohol ( $\geq 5$ doses/occasion) & -0.890 & 0.937 & 0.343 & 0.631 & 0.976 & 0.518 \\
\hline
\end{tabular}

Note: "Moderate and vigorous physical activity - converted to log 10; SFA: Saturated Fatty Acids; SEM: Standard Error of Measurement; Lipids, SFA, sodium, and fibers adjusted for total calories. ${ }^{\ddagger}$ Final model adjusted for gender $(p<0.001)$.

Skin color $(p=0.794)$; family history of acute myocardial infarction $(p=0.717)$; age $(p=0.529)$; family history of high cholesterol ( $p=0.441)$; economic class ( $p=0.413)$; and low birth weight $(p=0.218)$ were excluded from the model because $p \geq 0.10$.

Past food intake, despite the strategies used for collecting information, depends on subjects' memory. Yet, despite the caution to ensure response privacy, variables related to smoking and alcohol intake may not be accurate. Furthermore, studies have found different associations or lack thereof between the lipid profile of adolescents and lifestyle variables.

Body mass index may be associated with high cholesterol levels in adolescents, even after adjustment for gender and family history of early myocardial infarction. Similar results were reported elsewhere ${ }^{9,14}$ suggesting that excess weight during adolescence may be associated with undesirable total cholesterol levels. On the other hand, other studies have not found an association between $\mathrm{BMI}$ and cholesterol in adolescents ${ }^{15,25}$.

High-Density Lipoprotein-cholesterol was not inversely associated with BMI adjusted for gender, indicating that adolescents with high BMI have low levels of $\mathrm{HDL}-\mathrm{C}$. Other studies done in Brazil $^{8,15}$ and elsewhere ${ }^{13,26}$ also found an inverse association between HDL-c and overweight or obesity. Since HDL-c is antiatherogenic, low levels predispose to cardiovascular diseases.
These findings are worrisome because there is a global pandemic of overweight during adolescence ${ }^{27}$ which may tend to favor a higher prevalence of dyslipidemia in this age group. Additionally, dyslipidemia and overweight have an important role among the factors associated with the intima-media thickening of the coronary and carotid arteries, which is considered an early marker of atherosclerotic disease ${ }^{2,3}$. The interrelationship and synergy between these cardiovascular risk factors already during adolescence may precipitate other health problems in this population and contribute to the morbidity and mortality related to early cardiovascular events during adulthood.

Overweight is caused by many factors, that is, it is influenced by the environment, metabolism, and biology, and is considered a modifiable cardiovascular risk factor ${ }^{28,29}$. Environmental issues are measured by lifestyle, which influences the nutritional status and consequently, adolescent serum lipids. A longitudinal study that examined the effect of lifestyle changes on the stability of serum lipids in youth and adults found that positive changes, such as control of body weight, physical activity, 
not smoking, and better socioeconomic status may help to prevent dyslipidemia during adulthood $^{30}$. What is more, maintaining a healthy body weight is critical for preventing dyslipidemia in adolescence and maintaining an appropriate lipid profile in adulthood 5,7 .

This study has some limitations, such as using a typical day to determine diet, especially considering that weekday and weekend meals tend to vary, and the study did not take into account those variations. Although this type of instrument is individual and sensitive to cultural differences, it may facilitate food intake over- or underreporting, resulting in information bias ${ }^{23}$. Another limitation is the use of a questionnaire to determine the level of physical activity, since this method depends on the subjects' ability to remember and estimate precisely the parameters of the activities that are being measured.

However, the study also has some strengths, such as the use of a representative sample of school adolescents and the simultaneous analysis of anthropometric and lifestyle variables considered important confounding factors, such as family history of high cholesterol, family history of early myocardial infarction, low birth weight, age, gender, skin color, and economic class.

In conclusion, high BMI contributes to the negative lipid profile of adolescents. Multidisciplinary and intersectoral public health actions are suggested to prevent and control excess weight and consequently, dyslipidemia in adolescents, especially education and health actions. In this context, the school may be the main intervenor, preferably through the discipline physical education, which can develop educational situations that encourage adolescents to adopt healthy life habits, with emphasis on autonomous physical activities and an active lifestyle.

\section{A C KNOWLEDGMENTS}

We thank the Municipal Health Department from Três de Maio (RS) for supporting the study and for sponsoring the study.

\section{ONTRIBUTORS}

CC BECK conceived and designed the study, created the study protocol, coordinated and supervised data collection, analyzed and interpreted the data, wrote and reviewed the manuscript, and approved the final version of the manuscript. AS LOPES helped to conceive the study, review the manuscript, and interpret the results; approved the final version of the manuscript. JC FARIAS JÚNIOR analyzed the data, interpreted the results, reviewed the manuscript, and approved the final version of the manuscript.

\section{REFERENCES}

1. Lloyd-Jones DM, Hong Y, Labarthe D, Mozaffarian D, Appel $L$, Greenlund K, et al. Defining and setting national goals for cardiovascular health promotion and disease reduction: The American Heart Association's Strategic Impact Goal Through 2020 and Beyond. Circulation. 2010; 21:586-613. doi: 10.1161/CIRCULATIONAHA.109.192703

2. Li S, Chen W, Srinivasan SR, Bond MG, Tang R, Urbina EM, Berenson GS. Childhood cardiovascular risk factors and carotid vascular changes in adulthood: The Bogalusa heart study. Jama. 2003; 290(17):2271-6.

3. Dawson JD, Sonka M, Blecha MB, Lin W, Davis PH. Risk factors associated with aortic and carotid intima-media thickness in adolescents and young adults. J Am Coll Cardiol. 2009; 53(24):2273-9. doi: 10.1016/j.jacc.2009.03.026

4. McGill HC, McMahan CA, Herderick EE, Malcom GT, Tracy RE, Strong JP. Origin of atherosclerosis in childhood and adolescence. Am J Clin Nutr. 2000; 72(Suppl):1307S-15S.

5. Webber LS, Srinivasan SR, Wattigney WA, Berenson GS. Tracking of serum lipids and lipoproteins from childhood to adulthood: The Bogalusa heart study. Am J Epidemiol. 1991; 133(9):884-99.

6. Juhola J, Magnussen CG, Viikari JS, Kähönen M, Hutri-Kähönen $N$, Jula $A$, et al. Tracking of serum lipid levels, blood pressure, and body mass index from childhood to adulthood: The cardiovascular risk in young finns study. J Pediatr. 2011; 159(4):584-90. doi: 10.1016/j.jpeds.2011.03.021

7. Beck CC, Lopes AS, Giuliano ICB, Borgatto AF. Fatores de risco cardiovascular em adolescentes de município do sul do Brasil: prevalência e associações com variáveis sociodemográficas. Rev Bras Epidemiol. 2011; 14(1):36-49. doi: 10.1590/S141 5-790X2011000100004 
8. Pereira PB, Arruda IK, Cavalcanti AM, Diniz AS. Lipid profile of schoolchildren from Recife, PE. Arq Bras Cardiol. 2010; 95(5):606-13. doi: 10.1590/S0066-78 2X2010005000136

9. Giuliano IC, Coutinho MS, Freitas SF, Pires MM, Zunino JN, Ribeiro RQ. Lípides séricos em crianças e adolescentes de Florianópolis, SC: Estudo Floripa Saudável 2040. Arq Bras Cardiol. 2005; 85(2):85-91.

10. Pedrozo WR, Bonneau G, Castillo Rascón MS, Juárez M, Cardozo J. Reference values and prevalence of lipidic profile alterations in adolescents. Arch Argent Pediatr. 2010; 108(2): 107-15.

11. Magkos F, Manios Y, Christakis G, Kafatos AG. Secular trends in cardiovascular risk factors among school-aged boys from Crete, Greece, 1982-2002. Eur J Clin Nutr. 2005; 59(1):1-7.

12. Guedes DP, Guedes JERP, Barbosa DS, Oliveira JA, Stanganelli LCR. Fatores de risco cardiovasculares em adolescentes: indicadores biológicos e comportamentais. Arq Bras Cardiol. 2006; 86(6):439-50.

13. Velasco-Martínez RM, Jiménez-Cruz A, Higuera Domínguez F, de la Piedra ED, Bacardí-Gascón M. Obesidad y resistencia a la insulina en adolescentes de Chiapas. Nutr Hosp. 2009; 24(2):187-92.

14. Jago R, Drews KL, McMurray RG, Thompson D, Volpe SL, Moe EL, et al. Fatness, fitness, and cardiometabolic risk factors among sixth-grade youth. Med Sci Sports Exerc. 2010; 42(8):1502-10. doi: 10.1249/MSS.0b013e3181d322c4

15. Ribeiro RQ, Lotufo PA, Lamounier JA, Oliveira RG, Soares JF, Botter DA. Additional cardiovascular risk factors associated with excess weight in children and adolescents: The Belo Horizonte heart study. Arq Bras Cardiol. 2006; 86(6):408-18.

16. Franko DL, Albertson AM, Thompson DR, Barton $B A$. Cereal consumption and indicators of cardiovascular risk in adolescent girls. Public Health Nutr. 2011; 14(4):584-90. doi: 10.1017/\$1368980 010002016

17. Brasil. Ministério da Saúde. Departamento de Informação do SUS. Brasília: Ministério da Saúde; 2006 [acesso 2011 ago 17]. Disponível em: <http:// tabnet.datasus.gov.br/cgi/tabcgi.exe?ibge/cnv/ poprs.def>.

18. Associação Brasileira de Empresas de Pesquisa. Critério de Classificação Econômica Brasil. São Paulo: Abep; 2003 [acesso 2005 nov 26]. Disponível em: $<$ http://www.abep.org/new/>.

19. Telford A, Salmon J, Jolley D, Crawford D. Reliability and validity of physical activity questionnaires for children: The Children'S Leisure Activities Study Survey (CLASS). Pediatr Exerc Sci. 2004; 16:64-78.

20. Bressan J, Esteves E. Sistema de suporte de avaliação nutricional e avaliação de dietas. DietPro [programa de computador]. Versão 4.0. Minas Gerais: Agromídia software; 2001.

21. Global School-Based Student Health Survey. Chile GSHS Questionnaire. Geneva: WHO; 2004 [cited 2006 Mar 1]. Available from: <www.who.int/entity/ chp/gshs/Chile_questionnaire_english_2004.pdf>.

22. Alvarez, BR, Pavan AL. Alturas e comprimentos. In: Petroski EL. Antropometria: técnicas e padronizações. Santa Maria: Pallotti; 2005.

23. Willet W. Nutritional epidemiology. $2^{\text {nd }}$ ed. New York: Oxford University Press; 1998.

24. LeBlanc AG, Janssen I. Dose-response relationship between physical activity and dyslipidemia in youth. Can J Cardiol. 2010; 26(6):201-5.

25. Martinez-Gomez D, Rey-López JP, Chillón P, GómezMartínez S, Vicente-Rodríguez G, Martín-Matillas $M$, et al. Excessive TV viewing and cardiovascular disease risk factors in adolescents: The AVENA crosssectional study. BMC Public Health. 2010; 25(10): 274.

26. Denney-Wilson E, Hardy LL, Dobbins T, Okely AD, Baur LA. Body mass index, waist circumference, and chronic disease risk factors in Australian adolescents. Arch Pediatr Adolesc Med. 2008; 162(6):566-73.

27. Swinburn BA, Sacks G, Hall KD, McPherson K, Finegood DT, Moodie ML, et al. The global obesity pandemic: Shaped by global drivers and local environments. Lancet. 2011; 378(9793): 804-14.

28. Wanderley EN, Ferreira, VA. Obesidade: uma perspectiva plural. Ciênc Saúde Colet. 2010; 15(1): 185-94.

29. Farias ES, Santos AP, Farias-Júnior JC, Ferreira CRT, Carvalho WRG, Gonçalves EM, et al. Excesso de peso e fatores associados em adolescentes. Rev Nutr. 2012; 25(2):229-36. doi: 10.1590/S1415-52 732012000200005

30. Magnussen CG, Thomson R, Cleland VJ, Ukoumunne OC, Dwyer T, Venn A. Factors affecting the stability of blood lipid and lipoprotein levels from youth to adulthood: Evidence from the childhood determinants of adult health study. Arch Pediatr Adolesc Med. 2011; 165(1):68-76.

Received on: 15/1/2013

Final version on: 4/11/2013

Approved on: 4/12/2013 
